\title{
Evaluatie van de voorlichting aan ouders over de hielprik
}

\author{
Sylvia van der $\mathrm{Pal}^{1}$, Wilma Otten ${ }^{1}$, Symone Detmar ${ }^{1}$
}

\begin{abstract}
De hielprik is per januari 2007 uitgebreid van drie naar zeventien ziektes. Tevens kunnen ouders kiezen of zij een dragerschapuitslag op sikkelcelziekte willen ontvangen. Via vragenlijstonderzoek is nagegaan in hoeverre ouders een geïnformeerde beslissing nemen over deelname aan de hielprikscreening en over het ontvangen van een dragerschapuitslag. De resultaten laten zien dat $83 \%$ van de ouders een geïnformeerde keuze maakt om aan de hielprik deel te nemen; $58 \%$ heeft een geïnformeerde keuze gemaakt omtrent het ontvangen van de dragerschapuitslag op sikkelcelziekte. Geïnformeerde beslissingen werden minder vaak genomen wanneer de hielprik in het ziekenhuis werd afgenomen en wanneer ouders een lage sociale economische status hadden. Uit deze resultaten kan geconcludeerd worden dat vooral de voorlichting over de hielprik in het ziekenhuis, aan ouders met een lage sociaal economische status en over dragerschap extra aandacht verdient.
\end{abstract}

Trefwoorden: hielprik, voorlichting, screening, dragerschap, sikkelziekte

\section{INLEIDING}

Op grond van het advies van de Gezondheidsraad over de neonatale screening, ${ }^{1}$ wordt sinds 1 januari 2007 het bloed van pasgeborenen niet meer op drie maar op zeventien ziekten getest. Tevens krijgen ouders nu de keuze aangeboden geïnformeerd te worden over dragerschap van sikkelcelziekte van hun kind. Het voorlichtingsmateriaal en de voorlichtingsmomenten rondom de hielprik zijn sindsdien ook uitgebreid.

Deelname aan de hielprik is niet verplicht. De Gezondheidsraad acht het van belang dat er een goed geïnformeerde keuze gemaakt wordt om aan de hielprik deel te nemen en om de dragerschapuitslag (niet) te ontvangen. Het begrip "geïnformeerde keuze" is een keuze gebaseerd op voldoende en relevante kennis en overeenkomend met de normen en waarden (attitude) van het individu. $^{2}$

Voor een goed geïnformeerde keuze rondom de hielprik dienen ouders een aantal basisaspecten van erfelijkheid en dragerschap te kennen. Informatie over de dragerschapstatus van het kind heeft bijvoorbeeld gevolgen voor toekomstige zwangerschappen van de betreffende ouders en tezijnertijd van het kind zelf. Het belang van goede voorlichting is derhalve evident, hetgeen ook in eerder onderzoek en in het rapport van de Gezondheidsraad wordt benadrukt. ${ }^{1,3}$

Het Centrum voor Bevolkingsonderzoek (CvB) van het RIVM (Rijksinstituut voor Volksgezondheid en
Milieu) coördineert de hielprikscreening en voorlichting. Voor de ouders is er een folder met beknopte informatie en een website met uitgebreide informatie ontwikkeld. Voor de uitvoerders is er een checklijst gemaakt met alle onderwerpen die besproken dienen te worden (te raadplegen op de RIVM website: www.rivm.nl/pns/hielprik/ uitvoering/). ${ }^{4}$ Bovendien zijn er bij- en nascholingscursussen ontwikkeld over de voorlichting voor verloskundig hulpverleners en neonatale screeners (speciaal opgeleide mensen voor het thuis afnemen van de hielprik en de gehoorscreening).

De verloskundig hulpverleners geven, sinds januari 2007 , in het laatste trimester van de zwangerschap voorlichting over de hielprik en delen de hielprikfolder uit aan ouders. De neonatale screeners, die de hielprik uitvoeren, vragen ouders of zij de informatie en folder hebben ontvangen en eventueel nog vragen hebben. Ook kunnen ouders op dat moment aangeven dat zij een uitslag van dragerschap op sikkelcelziekte niet willen ontvangen.

Gezien het belang van een geïnformeerde keuze over deelname aan de hielprikscreening en over het ontvangen van de dragerschapuitslag op sikkelcelziekte, dient de voorlichting over de uitgebreide hielprik geëvalueerd te worden. Dit evaluatieonderzoek beoogt een eerste inventarisatie van mogelijke knelpunten in de informatievoorziening naar ouders.

\footnotetext{
${ }^{1}$ TNO Kwaliteit van Leven, Preventie en Zorg, Leiden
} 


\section{METHODE}

\section{Vragenlijst}

Het Erasmus MC heeft een vragenlijstmethodiek ontwikkeld om de voorlichting over pre- en neonatale screening landelijk te evalueren. ${ }^{5}$ Deze vragenlijst is gebaseerd op de Multidimensional Measure of Informed Choice van Marteau et al. en bevat items die de attitude (4 items) en relevante kennis (10 items) over de hielprik bij de doelgroep meten. ${ }^{2,5}$ Deze attitude en kennisitems voor het evalueren van de voorlichting over de neonatale screening zijn door TNO aangepast om specifiek de neonatale screening te kunnen evalueren; er zijn vier kennisitems toege-

voegd en er werden vijf in plaats van vier attitude items gebruikt, waarbij ook om de attitude gevraagd werd ten opzichte van het ontvangen van een dragerschapuitslag. De Cronbach's alpha van de kennisschaal was 0,69 (14 items; de 10 oorspronkelijke kennisitems van de Erasmuc MC vragenlijst geven een alpha van 0,58$)$. De Cronbach's alpha van de attitudeschaal met betrekking tot de hielprik is 0,68 en die met betrekking tot de vraag of het kind drager is 0,81 (beide schalen hebben 5 items). Daarnaast is een aantal items toegevoegd die betrekking hebben op de ervaringen van ouders met de voorlichting door verschillende zorgprofessionals (zoals de verloskundig hulpverleners, neonataal screeners en kraamverzorgenden). Tot slot werden enkele achtergrondgegevens gevraagd. De vragenlijst bevatte 42 vragen en het invullen kostte ouders ongeveer vijftien minuten.

\section{Versturen vragenlijsten}

In de methodiek, beschreven door het Erasmus MC, is het advies gegeven om gedurende twee weken alle gezinnen die zich aanmelden voor een hielprik aan te schrijven met een beoogde respons van $50 \% .^{5}$ In totaal zijn vanuit de RIVM-RCP's (Regionale Coördinatie Programma's) 7.784 vragenlijsten verstuurd naar de adressen van alle ouders die van 7 tot en met 22 april 2008 zijn aangemeld bij de RIVM-RCP's voor een hielprik.

Twee weken na het versturen van de vragenlijst is een herinneringskaartje naar alle ouders gestuurd. Om ouders te stimuleren de vragenlijst in te vullen zijn tien cadeaubonnen van 50 euro voor babyartikelen verloot onder de gezinnen die de vragenlijst terugstuurden. Verder konden ouders per email of telefoon een Engelstalige versie van de vragenlijst opvragen.

\section{Data-analyse}

De vragenlijsten zijn in SPSS 14.0 ingevoerd en geanalyseerd. Allereerst is gekeken naar de representativiteit van de steekproef door de achtergrondgegevens te vergelijken met de meest recente gegevens binnen de algemene Nederlandse populatie van het Centraal Bureau voor de Statistiek (CBS; http://statline.cbs.nl/). Vervolgens is gekeken in hoeverre ouders een geïnformeerde keuze gemaakt hadden (in overeenstemming met hun attitude en kennis). De berekening hiervoor is overgenomen uit het rapport van het Erasmus MC. ${ }^{5}$ De kennisschaal werd omgescoord zodat de scores liepen van 0 (alle vragen fout beantwoord) tot 10 (alle vragen goed beantwoord). Een kennisscore van $\geq 6$ is voldoende kennis (dit betekent dat 9 of meer van de 14 kennisvragen correct beantwoord zijn); $<6$ is onvoldoende kennis. De attitudeschaal werd ook omgescoord naar een score van 0 tot 10 , waarbij een attitudescore van $\geq 6$ een positieve attitude weergeeft en een score van $<6$ een negatieve attitude. Een goed geïnformeerde keuze is gemaakt indien ouders met voldoende kennis en een positieve attitude kiezen voor deelname óf indien ouders met voldoende kennis en een negatieve attitude kiezen voor niet-deelname (Tabel 1). Hetzelfde geldt voor de keuze omtrent het ontvangen van een dragerschapuitslag sikkelcelziekte.

Verschillen in de kennis- en attitudescores tussen ouders (hoge vs. lage opleiding, autochtonen vs. allochtonen) en plaats van afname (in het ziekenhuis vs. thuis) zijn nagegaan met een t-test (bij 2 categorieën) of een univariate variantieanalyse (bij meer dan twee categorieën). Het verschil in de uiteindelijke keuze tussen deze groepen ouders is met een chi-kwadraat toets bekeken.

Descriptieve statistiek (aantallen, valide percentages en kruistabellen) is gebruikt om de antwoorden van ouders over de uitvoer van de voorlichting te exploreren.

Tabel 1 Wanneer wordt door ouders een goed geïnformeerde keuze gemaakt?

\begin{tabular}{lll}
\hline & onvoldoende kennis $(<6)$ & voldoende kennis $(\geq 6)$ \\
\hline negatieve attitude $(<6)$ & geen goed geïnformeerde keuze & bij niet deelname: goed geïnformeerde keuze \\
positieve attitude $(\geq 6)$ & geen goed geïnformeerde keuze & bij deelname: goed geïnformeerde keuze \\
\hline
\end{tabular}




\section{RESULTATEN}

\section{Teruggestuurde vragenlijsten}

Er zijn in totaal 3593 vragenlijsten teruggestuurd (46\% respons). Per gezin werd een ouder gevraagd de vragenlijst in te vullen. Er werd zes maal om een Engelstalige vragenlijst gevraagd. De vragenlijsten zijn voornamelijk door moeders (86\%) ingevuld.

De gemiddelde leeftijd (van moeder) was 31,5 jaar en dit is vergelijkbaar met de CBS Statline gegevens (jaar 2006). Deze steekproef bleek hoger opgeleid (32\% HBO, $17 \% \mathrm{WO}$ ) vergeleken met de CBS gegevens (23\% HBO, $14 \%$ WO; in 2006; potentiële beroepsbevolking, vrouwen 25-35 jaar). De respons bleek goed verspreid over $\mathrm{Ne}$ derland, aangezien de verdeling van deelnemers per postcode (duizendtal) niet verschilde van het percentage inwoners per postcode (CBS; leeftijd 20-40). Ook het aantal kinderen en de burgerlijke staat van ouders waren vergelijkbaar met de CBS gegevens. Volgens de CBS-gegevens van de algehele populatie is in 2008 9,9\% van de bevolking allochtoon (eerste generatie, Westers: 3,7\%, Niet-Westers: 6,2\%). Binnen onze steekproef is een vergelijkbaar percentage van $11 \%$ allochtoon gevonden (Westers: 3\%, Niet-Westers: 8\%). Ook binnen de ouders die niet in Nederland geboren zijn is een hoog percentage hoger opgeleiden te vinden (HBO 21,5\% en WO 17\%).

\section{Kennis, attitude en geïnformeerde keuze}

Tabel 2 geeft de verdeling weer van geïnformeerde keuzes met betrekking tot deelname aan de hielprik. 83\% van de respondenten (2695 van de 3250) heeft een goed geïnformeerde keuze gemaakt om aan de hielprik deel te nemen. De $17 \%$ die geen goed-geïnformeerde keuze maakte, bestond vooral uit ouders die deelnamen aan de hielprik met een positieve attitude maar met onvoldoende kennis (15\%). Slechts één ouder weigerde deel- name aan de hielprik. Deze persoon had inderdaad een negatieve attitude, echter ook onvoldoende kennis. Een onvoldoende kennisscore van ouders bleek vooral op de kennisitems 13 en 14 waarbij een hoog percentage ouders (respectievelijk 34\% en 29\%) "weet niet" hebben geantwoord. Item 13 bevatte de stelling: "Als een kind drager is van sikkelcelziekte, dan is één of beide ouders ook drager van sikkelcelziekte" (stelling is waar) en item 14: "Na het onderzoek worden de bloeddruppels direct vernietigd" (stelling is niet waar).

Van de ouders heeft 58\% (1879 van de 3261 ouders) een goed geïnformeerde keuze gemaakt omtrent het (niet) ontvangen van dragerschapuitslag op sikkelcelziekte (Tabel 3). Van de $42 \%$ die geen geïnformeerde keuze heeft gemaakt, had $11 \%$ onvoldoende kennis $(n=288)$. Ouders weten bijvoorbeeld vaak niet dat kennis over dragerschap van hun kind voor henzelf relevant is in verband met eventuele volgende zwangerschappen. 20\% gaf aan deze keuze überhaupt nooit aangeboden te hebben gekregen en $11 \%$ wist niet meer of zij deze keuze aangeboden hebben gekregen. Ook deze ouders hebben vaak onvoldoende kennis.

Drie-en-zestig ouders hebben op het hielprikkaartje aan laten kruisen geen uitslag op dragerschap van sikkelcelziekte te willen ontvangen (Tabel 3). De ouders die dit aangaven hebben over het algemeen voldoende kennis (58 van de 63).

De redenen van ouders om de dragerschapuitslag op sikkelcelziekte niet te willen weten waren vooral dat ouders de meerwaarde niet inzagen, de kans op dragerschap door de autochtone afkomst van het kind als klein inschatten of omdat de gevolgen (stempel op het kind) voor hen onduidelijk zijn. Bij de redenen om de dragerschapuitslag op sikkelcelziekte wél te willen weten werden vooral redenen genoemd zoals "omdat het goed is om te weten voor de toekomst" of "omdat alle informatie over

Tabel 2 Geïformeerde keuze deelname hielprik

\begin{tabular}{|c|c|c|c|c|}
\hline Deelname hielprik & Ja & Nee & Weet niet & Totaal \\
\hline Onvoldoende kennis \& Negatieve attitude & $19(0,6 \%)$ & $1(0,03 \%)$ & $2(0,06 \%)$ & $22(0,6 \%)$ \\
\hline Onvoldoende kennis \& Positieve attitude & $493(15 \%)$ & 0 & $1(0,03 \%)$ & $494(15 \%)$ \\
\hline Voldoende kennis \& Negatieve attitude & $38(1,2 \%)$ & 0 * & 0 & $38(1,2 \%)$ \\
\hline Voldoende kennis \& Positieve attitude & $2695(83 \%)^{\star}$ & 0 & $1(0,03 \%)$ & $2696(83 \%)$ \\
\hline Totaal & $3245(99,8 \%)$ & $1(0,03 \%)$ & $4(0,1 \%)$ & $3250(100 \%)$ \\
\hline
\end{tabular}

* Goed geïnformeerde keuze (zie Tabel 1)

Noot De aantallen komen niet overeen met de totale aantallen in verband met niet (volledig) ingevulde kennis, attitude of keuze-items.

Tabel 3 Geïnformeerde keuze niet willen ontvangen van dragerschapuitslag sikkelcelziekte

\begin{tabular}{|c|c|c|c|c|c|}
\hline Keuze dragerschapuitslag & $\begin{array}{l}\text { Niets laten aankrui- } \\
\text { sen; ontvangt wel } \\
\text { drageruitslag }\end{array}$ & $\begin{array}{l}\text { Aankruisen "wil niet } \\
\text { ontvangen } \\
\text { drageruitslag" }\end{array}$ & $\begin{array}{l}\text { Keuze niet } \\
\text { aangeboden }\end{array}$ & Weet niet meer & Totaal \\
\hline $\begin{array}{l}\text { Onvoldoende dragerkennis }{ }^{\star \star} \& \\
\text { Negatieve attitude }\end{array}$ & $16(0,5 \%)$ & 0 & $22(0,7 \%)$ & $19(0,6 \%)$ & $57(2 \%)$ \\
\hline $\begin{array}{l}\text { Onvoldoende dragerkennis }{ }^{\star \star} \& \\
\text { Positieve attitude }\end{array}$ & $267(8 \%)$ & $5(0,15 \%)$ & 296 (9\%) & $167(5,1 \%)$ & 735 (22\%) \\
\hline $\begin{array}{l}\text { Voldoende dragerkennis }{ }^{\star \star} \& \\
\text { Negatieve attitude }\end{array}$ & $58(1,8 \%)$ & $20(0,6 \%)^{\star}$ & $14(0,4 \%)$ & $9(0,3 \%)$ & 101 (3\%\%) \\
\hline $\begin{array}{l}\text { Voldoende dragerkennis }{ }^{\star \star} \& \\
\text { Positieve attitude }\end{array}$ & $1859(57 \%)^{\star}$ & $38(1,2 \%)$ & $310(9,5 \%)$ & 161 (4,9\%) & $2368(73 \%)$ \\
\hline Totaal & $2200(67 \%)$ & $63(2 \%)$ & $642(20 \%)$ & $356(11 \%)$ & $3261(100 \%)$ \\
\hline
\end{tabular}

* Goed geïnformeerde keuze (zie Tabel 1)

** Alleen 4 kennisvragen meegenomen waarin naar aspecten van dragerschap gevraagd wordt

Noot De aantallen komen niet overeen met de totale aantallen in verband met niet (volledig) ingevulde kennis, attitude of keuze-items. 
de gezondheid van mijn kind welkom is". Er lijkt in enkele gevallen verwarring over het begrip "drager" aangezien ouders spreken over een "ziekte" of "behandeling" (bijvoorbeeld; "dan weet ik of mijn kind de ziekte heeft").

\section{Verschil in kennis en attitude tussen groepen}

Tabel 4 laat zien dat ouders een significant lagere kennisscore $(\mathrm{p}<0,001)$ hebben wanneer ze laag opgeleid of niet in Nederland geboren zijn of wanneer de hielprik in het ziekenhuis afgenomen is, in vergelijking met ouders die hoog opgeleid zijn of in Nederland geboren zijn of wanneer de baby thuis geprikt is. Ouders die laag opgeleid of niet in Nederland geboren zijn hebben ook een minder positieve attitude ten opzichte van de hielprik $(p<0,001$ en $p=0,002)$. Ouders, bij wie het kind in het ziekenhuis geprikt is, geven significant vaker aan dat de keuze om de dragerschapuitslag sikkelcelziekte (wel/niet) te ontvangen hen niet is voorgelegd, in vergelijking met ouders waarbij de hielprik thuis afgenomen is $(60 \%$ vs. $14 \%)$.

\section{Beoordeling voorlichting hielprik door ouders}

Ouders geven de voorlichting een gemiddeld rapportcijfer van 7,2 en beoordelen de voorlichting over het algemeen als duidelijk, prettig, makkelijk, voldoende, iets te laat en iets te weinig. Ouders worden het vaakst door de verloskundig hulpverlener $(\mathrm{n}=1980,55 \%$ van alle ouders) en de kraamverzorgende ( $\mathrm{n}=1943,54 \%$ van alle ouders) geïnformeerd. Wanneer ouders gevraagd wordt welk van alle informatiebronnen voor hen de belangrijkste was, worden de screener (26\%) en de folder (26\%) het meest aangekruist. Ook kriigen deze informatiebronnen het hoogste gemiddelde rapportcijfer (respectievelijk een 7,2 en een 7,2). De website over de hielprik (www.rivm.nl/hielprik) kreeg een gemiddeld rapportcijfer van 6,9 , waarbij $81 \%$ van de respondenten geen cijfer kon geven omdat zij deze website niet geraadpleegd heeft. De hielprikfolder wordt door $36 \%$ in zijn geheel gelezen, $14 \%$ heeft de folder niet gelezen en $14 \%$ geeft aan de folder niet te hebben ontvangen.

\section{DISCUSSIE}

De meeste ouders staan positief tegenover de uitgebreide hielprik en de bijbehorende voorlichting en keuzes.
Ouders maken over het algemeen een geïnformeerde keuze voor deelname aan de hielprik. Een ongeïnformeerde keuze werd voornamelijk veroorzaakt door een tekort aan kennis. Enkele ouders hebben in de opmerkingen toegelicht dat zij bij voorbaat minder goed naar de voorlichting geluisterd hebben omdat zij reeds een onbetwiste keuze voor deelname hadden gemaakt. Het blijft echter van belang dat ouders goed geïnformeerd zijn over testen die hun kinderen ondergaan. Daarnaast blijkt de kennisscore van ouders met een lage opleiding, ouders die niet in Nederland geboren zijn en wanneer de hielprik in het ziekenhuis afgenomen is, lager dan gemiddeld, waardoor het van belang is bij deze groepen extra inspanningen te leveren bij de voorlichting.

Bij de keuze om de dragerschapuitslag op sikkelcelziekte te ontvangen makte $58 \%$ van de ouders een geinformeerde keuze. Van de ouders die geen geïnformeerde keuze maakte, gaf een deel aan dat deze keuze niet was voorgelegd aan hen of dat men niet meer wist of deze keuze was voorgelegd. Bij de overige ouders bleek een ongeïnformeerde keuze meestal gebaseerd op onvoldoende kennis. Veel ouders realiseren zich bijvoorbeeld niet dat kennis over dragerschap vooral voor henzelf relevant is met betrekking tot een volgende zwangerschap. Deze reproductieve keuze voor ouders is echter een belangrijke doelstelling van deze neonatale dragerschapscreening, zoals ook aangegeven op pagina 37 in het rapport van de gezondheidsraad. ${ }^{1}$

Vooral wanneer de hielprik in het ziekenhuis was afgenomen, gaven ouders aan dat zij geen keuzes voorgelegd hebben gekregen. Voor zorgverleners in het ziekenhuis bestaat (nog) geen standaard informatieprotocol m.b.t. de voorlichting over de hielprik. Ook kraamverzorgenden worden momenteel niet opgenomen in de informatieprotocollen voor zorgverleners, maar blijken wel een grotere rol te spelen in de informatievoorziening naar ouders toe dan verwacht. Het zou interessant zijn om inzicht te verkrijgen in de informatie die kraamverzorgenden over het algemeen geven.

\section{CONCLUSIE}

Dit onderzoek laat zien dat een aantal aspecten binnen de voorlichting over de hielprik extra aandacht verdient. ${ }^{9} \mathrm{De}$ voorlichting dient aangepast te worden voor ouders met

Tabel 4 Verschil in kennis en attitude ten opzichte van de hielprik

\begin{tabular}{|c|c|c|c|c|c|}
\hline Plaats afname & $\begin{array}{l}\text { Thuis } \\
\text { (gemiddelde) }\end{array}$ & & $\begin{array}{l}\text { Ziekenhuis } \\
\text { (gemiddelde) }\end{array}$ & Verschil $(95 \% \mathrm{Cl})$ & p-waarde* \\
\hline $\begin{array}{l}\text { Kennis-score } \\
\text { Attitude hielprik }{ }^{\star \star \star}\end{array}$ & $\begin{array}{l}7,88 \\
9,38 \\
\end{array}$ & & $\begin{array}{l}7,12 \\
9,32 \\
\end{array}$ & $\begin{array}{l}0,76(0,56 ; 0,96) \\
0,07(-0,20 ; 0,33)\end{array}$ & $\begin{array}{l}<0,001 \\
0,63\end{array}$ \\
\hline Opleiding ouders & $\begin{array}{l}\text { Laag } \\
\text { (gemiddelde) }\end{array}$ & $\begin{array}{l}\text { Midden } \\
\text { (gemiddelde) }\end{array}$ & $\begin{array}{l}\text { Hoog } \\
\text { (gemiddelde) }\end{array}$ & Beta $(95 \% \mathrm{Cl})$ & p-waarde ${ }^{\star \star}$ \\
\hline 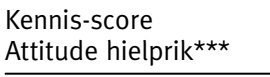 & $\begin{array}{l}6,78 \\
8,64 \\
\end{array}$ & $\begin{array}{l}7,75 \\
9,40 \\
\end{array}$ & $\begin{array}{l}8,10 \\
9,53\end{array}$ & $\begin{array}{l}-1,32(-1,48 ;-1,16) \\
-0,89(-1,16 ;-0,61\end{array}$ & $\begin{array}{l}<0,001 \\
<0,001\end{array}$ \\
\hline Geboorteland ouders & $\begin{array}{l}\text { Nederland } \\
\text { (gemiddelde) }\end{array}$ & & $\begin{array}{l}\text { Elders } \\
\text { (gemiddelde) }\end{array}$ & Verschil $(95 \% \mathrm{Cl})$ & p-waarde* \\
\hline $\begin{array}{l}\text { Kennis-score } \\
\text { Attitude hielprik }\end{array}$ & $\begin{array}{l}7,94 \\
9,43\end{array}$ & & $\begin{array}{l}6,23 \\
8,85\end{array}$ & $\begin{array}{l}1,70(1,47 ; 1,94) \\
0,58(0,22 ; 0,94)\end{array}$ & $\begin{array}{l}<0,001 \\
0,002\end{array}$ \\
\hline
\end{tabular}

* Two sample t-test

** Univariate variantie analyse (fixed factor=opleiding)

$\star \star \star$ Generieke attitude items (zoals ontwikkeld door Erasmus MC) 
een lagere opleiding en voor ouders die niet in Nederland geboren zijn. Bij deze groepen is het van belang voor zorgprofessionals om bij de voorlichting na te gaan of de basisaspecten en keuzes goed begrepen zijn. Daarnaast dient meer nadruk gelegd te worden op de extra keuze die ouders hebben om de dragerschapuitslag op sikkelcelziekte niet te ontvangen en wat dit voor ouders betekent, vooral binnen de niet-westerse allochtone hoogrisicogroepen. De voorlichting over dragerschap op sikkelcelziekte binnen de hielprik dient binnen deze groepen extra geëvalueerd te worden en waar mogelijk verbeterd te worden. Tot slot verdient de deskundigheidsbevordering bij afname in het ziekenhuis extra aandacht, zodat men zeker weet dat ouders goed geïnformeerd worden in deze setting.

\section{NoOT}

Dit onderzoek is gedaan dankzij de financiële steun vanuit het Centrum voor Bevolkingsonderzoek van het RIVM. De vragenlijst is in samenwerking met het CvB RIVM en met het Erasmus MC ontwikkeld en aangepast.

\section{ABSTRACT}

Evaluation of the health information for parents about the Dutch Neonatal Screening Program.

The neonatal screening program in the Netherlands was extended from three to seventeen diseases since January 2007. Also, from that point on parents had the opportunity to decide if they wanted to receive a carrier result of sickle cell disease for their child or not. Questionnaires were used to explore whether parents made an informed decision to let their child participate in neonatal screening. The results show that $83 \%$ of parents made an informed decision to let their child participate in the neonatal screening program. $58 \%$ of the parents made an informed decision whether to receive a carrier result of sickle cell disease for their child or not. A lower percentage of informed decisions was found among parents whose child was pricked in the hospital or when parents had lower social economic status. These findings show that health information about the Dutch neonatal screening program for parents with a low social economic status and in hospital needs further attention.

Keywords: neonatal screening program, informed decision, sickle cell disease, health education

\section{LITERATUUR}

1. Gezondheidsraad. Neonatale screening. Publicatienr 2005/11. Den Haag: Gezondheidsraad, 2005.

2. Marteau TM, Dormandy E, Michie S. A measure of informed choice. Health Expect 2001;4:99-108.

3. Detmar S, Hosli E, Dijkstra N, Nijsingh N, Rijnders M, Verweij $M$. Information and informed consent for neonatal screening: opinions and preferences of parents. Birth 2007;34:238-44.

4. RIVM. Checklist voor uitvoerders hielprik; voorlichting neonatale hielprikscreening. Bilthoven: RIVM bevolkingsonderzoek, 2009.

5. Agt HME van, Schoonen HMHJD, Wildschut HIJ, Koning HJ de, Essink-Bot ML.Voorlichting voor pre- en neonatale screeningsprogramma's; vragenlijsten voor landelijke evaluatie van de aanbiedingsprocedure. Eindrapportage. Rotterdam: Erasmus MC, afdeling maatschappelijke gezondheidszorg / verloskunde en vrouwenziekten, 2007.

6. Pal SM van der, Detmar SB. Tijdsmeting voorlichting hielprik door verloskundigen. Eindrapport KvL/P\&Z 2007.122. Leiden: TNO Kwaliteit van Leven, afdeling Jeugd, 2007.

7. Pal SM van der, Detmar SB. Tijdsmeting afname hielprik na uitbreiding neonatale screening. TNO Eindrapport KvL/P\&Z 2007.108. Leiden: TNO Kwaliteit van Leven, afdeling Jeugd, 2007.

8. Pal SM van der, Detmar SB. De uitgebreide hielprik: hoeveel tijd kost de afname? Tijdschr Jeugdgezondheidsz 2008;40(5): 97-101

9. Pal SM van der, Detmar $S B$. Evaluatie hielprik voorlichting 2008. TNO Eindrapport KvL/P\&Z 2008.105. Leiden: TNO Kwaliteit van Leven, afdeling Jeugd, 2008

\section{CORRESPONDENTIEADRES}

mw. dr. Sylvia van der Pal, TNO Kwaliteit van Leven, Preventie en Zorg, Wassenaarseweg 56, Postbus 2215, 2301 CE Leiden, tel. 071-5181317, e-mail: sylvia.vanderpal@tno.nl 